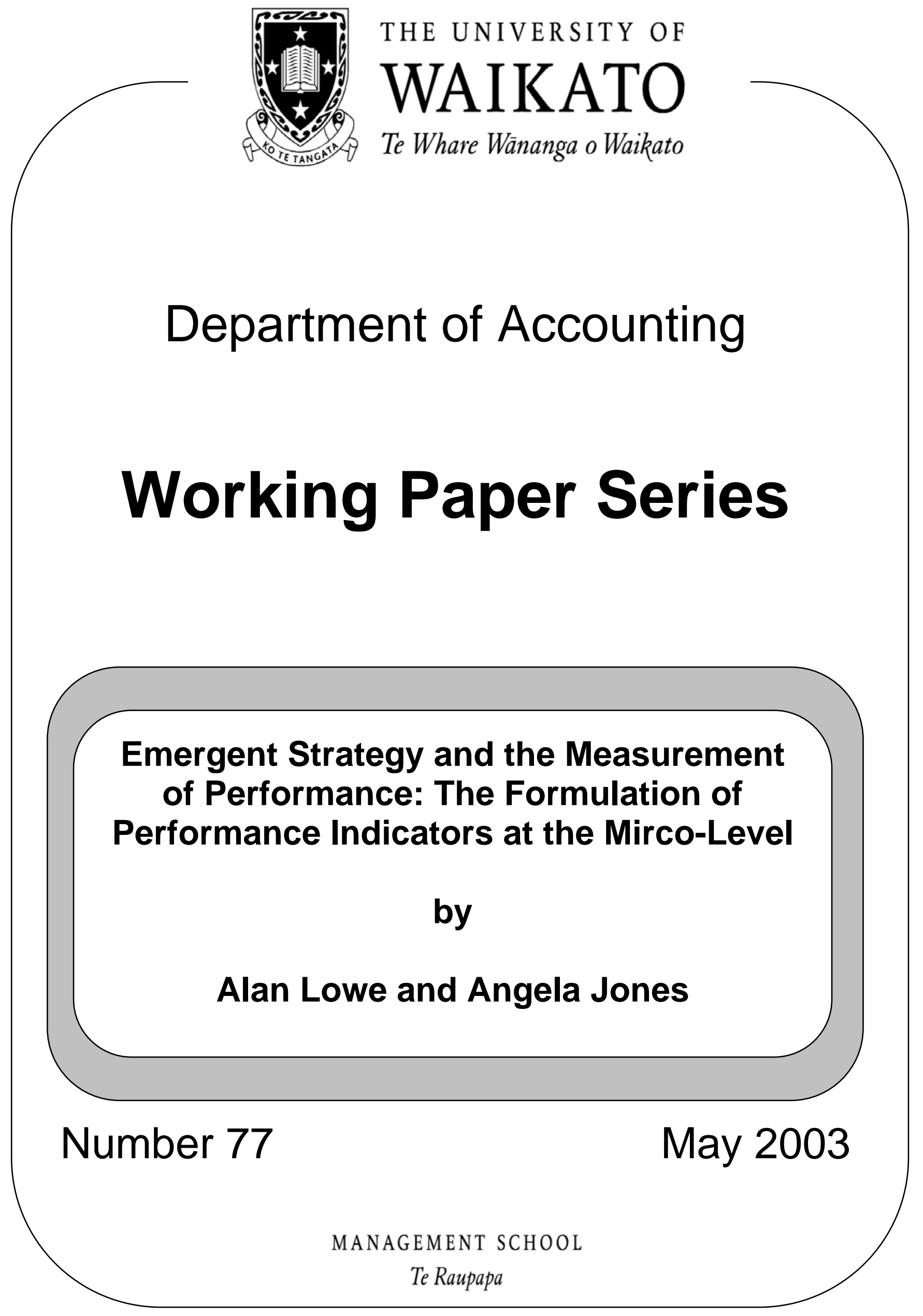


The Working Paper Series is published by the Department of Accounting, University of Waikato, and is intended to provide staff, visitors and postgraduate students with a forum for publishing developing research. The opinions expressed in the various papers in the Series are those of the author(s) and are not necessarily endorsed by the Department. Working Papers are preliminary in nature; their purpose is to stimulate discussion and comment, and any feedback from readers would be welcomed by the author(s).

Correspondence concerning the submission of manuscripts and the receipt of copy may be addressed to:

\author{
The Editor - Working Paper Series \\ Department of Accounting \\ University of Waikato \\ Private Bag 3105 \\ Hamilton, New Zealand \\ Fax: $0064(0) 78384332$
}

Correspondence concerning the reproduction of, or comment on, any part of a Paper should be addressed to the author(s) concerned. 


\title{
EMERgent Strategy AND THE MEASUREMENT OF PERFormance: THE Formulation Of PERformance INdiCATORS AT THE Micro- LEVEL
}

\author{
Alan Lowe* and Angela Jones \\ *Address for correspondence: \\ University of Waikato, New Zealand \\ Department of Accounting \\ University of Waikato \\ Private Bag 3105 \\ Hamilton \\ New Zealand \\ Tel: +64 78562889 \\ Fax: +64 78384332 \\ Email: alowe1@waikato.ac.nz
}

\begin{abstract}
This paper presents some evidence on an aspect of the design of a strategic control system, at the micro level within a single organisation. The research we report used an ethnographic approach to provide an understanding of strategy formulation. Our aim is to contribute to an area of literature which is of increasing significance but relatively underdeveloped in terms of the application of, in depth, field research techniques. We take an intensive look at the manner in which performance measures are formulated, at the micro level, within a single organization. The paper presents, as an in-depth case analysis, the experience of a fisheries holding company in New Zealand. The paper recounts the experiences of managers within the organization of the process of identification of such things as, critical success factors and key performance indicators (KPI's) and, more broadly the formulation of a strategic performance measurement system. A number of themes emerged during the research including as apparent reluctance to reduce a reliance on financial measures, the significance of functional boundaries which resulted in disagreements and misunderstandings, the importance of communication and the problems resulting from some managers apparently seeking to avoid attempts to fix responsibility.
\end{abstract}




\section{Introduction}

Mintzberg, Ahlstrand and Lampel (1998) argue that theorizing strategy 'is becoming much more eclectic... [and they wish to] celebrate its newfound messinness' (p372). In concluding their "Strategy Safari” they argue poignantly that 'we need good practice, not neat theory (ibid, p372). These writers call especially for a holistic approach to understanding strategy formulation.

It is now time to leave ... our libraries, classrooms, offices ... and plunge into the tangled wilds... We should certainly encourage scholars and consultants to continue probing the important elements of each school [of strategic management theory]. But, more importantly, we have to get beyond the narrowness of each school: we need to know how this beast called strategy formulation, which combines all of these schools and more, really lives its life. (Mintzberg, et al, 1998, p373)

This paper follows a research approach which aims to, at least, begin to open up the real life of one aspect of strategy formulation through an in depth study of a single organization. The use of a case study approach which is reported in this paper follows this call of Mintzberg, et al (1998) to 'plunge into the tangled wilds' and 'get beyond the narrowness' of a single 'school' of strategic management theory. The paper presents interview material and other case insights from a study of single organization as a way to explain strategy formulation at the micro level.

This paper seeks to contribute to the understanding of strategic management issues such as the role of techniques of performance management at the micro level. Recent literature has shown a significant interest in examining aspects of strategy formulation and process at the level of the individual manager (Johnson, 2000; Johnson et al, 2000). In this paper we report the interactions among the management team of a medium sized New Zealand fisheries company. The evidence we present later in the paper provides an understanding of individual motivations and the dynamic nature of team interactions in their efforts to design a system of performance management.

The research, which is presented in this paper relates to a longitudinal study carried out within a single organisation. The case study method was used in this research to develop an understanding of the softer issues of performance measurement systems such as formulation 
and communication. A case study approach allowed the researcher to see the processes involved in the development of a performance measurement system. A case research style was chosen as the most suitable because the central concern of the researchers was to develop a richness of understanding of the organization and the issues related to the design and development of a system of performance measurement. It has been argued that such depth of understanding may be lacking in other research methods (Langfield-Smith, 1997).

The case organisation is a medium sized fishery company registered in New Zealand. The company is owned by Maori ${ }^{1}$ and has been in existence since 1989 (becoming a registered limited liability company in 1994). Currently the company does not own vessels, but through contracting other vessels is able to catch a large proportion of the quota species it accesses. The company leases fishing quota from its Maori shareholders and owns a small quantity itself. In recent years the company has also sought to increase its quota base by leasing quota from other parties. Currently the case organisation accesses 22,000 tonnes of quota (the total quota available in New Zealand is currently in excess of 600,000 tonnes). The company uses six fishing vessels varying in size from 24 metres to 105 metres. The vessels stay at sea for periods of up to six weeks and employ up to 85 people on board. A majority of the product is exported to a wide range of European, Asian and Pacific countries.

The paper proceeds in the next section to outline the research methods deployed in the organization. This is followed by a brief review of the literature on strategic performance and strategy development, this is necessarily selective but seeks to provide some context for the remainder of the paper. The third section of the paper presents the case data and analysis and explanation of the themes that emerged during the research. This is followed by a discussion section which reconsiders two issues which seem particularly worthy of further consideration in view of the existing literature. The paper concludes with a brief summary section.

\section{Research Method}

The research utilised an interpretive research methodology and data collection was done through an ethnographic case study approach. The use of an interpretive methodology as a

\footnotetext{
${ }^{1}$ Maori was ceded ownership by the New Zealand government as part of the compensation agreed as a consequence of a claim under the Treaty of Waitangi.
} 
framework for researching organisations is supported by a number of authors (Alvesson and Deetz, 2000; Boland, 1993; Covaleski and Dirsmith, 1990; Dent, 1991; Llewellyn, 1993 and Morgan, 1988). This literature is not homogeneous but is characterised by its emphasis on providing research of an in-depth and rich nature. Llewellyn (1993) refers to two pieces of research undertaken about change in management accounting and finds that "there is knowledge of why accounting change occurred but there is little insight into how change was achieved” (1993, p. 243). Llewellyn argued that an interpretive approach would have provided a more complete understanding of the effect of ... change in the organisations researched. She further states that "any research that hopes to fully illuminate the process of ... change must work through an interpretive, if not a hermeneutic, methodology in order to demonstrate how change is accomplished through human agency” (p. 243).

This paper adopted an intensive case study approach to data collection in the research site. The aim of the research was to develop an in-depth understanding of the issues related to the development and implementation of a performance measurement system. A case study approach allowed the researcher to see first hand a company working through the process of developing a new performance measurement system. The process of developing the Key Performance Indicators (KPIs) at the case organisation extended over a six-month period. One of the researchers was in attendance at all formal meetings of staff on the development of KPIs (see appendix 1 for a list of meetings attended). In addition the participants were observed in their day to day work on an ad hoc basis over a period of over a year. By observing sessions and being on site with the case organisation, the researchers were able to develop an in-depth understanding of the people involved and the processes of interaction. Full transcripts of all the management team meeting sessions were prepared.

The next section will review some of the relevant literature strategy development and related issues of performance measurement. Following this the paper will present the case material and proceed to discuss the main themes and issues arising from the case research will be presented in the following section.

\section{Understanding Strategy at the Micro Level}


The existing literature has addressed aspects of strategy formulation from a variety of perspectives. Cognitive aspects of individuals and groups of managers have been the subject of some of this research using psychological approaches (Eden, 1993; Hellgren and Melin, 1993) or a mix of psychological and sociological approaches (Johnson et al, 2000). Johnson et al (2000) examine the value of an institutional theory perspective in conceptualising the interactive effects of privatisation. These writers describe their theoretical approach as a micro-institutional perspective and discuss, at the conceptual level, the change processes which institutions subject to privatisation experience in terms of differences in "institutional templates", "institutional rules" and the development of individual cognitive schema or “scripts”.

The concept of emergent strategy as opposed to deliberate strategy, is central to the theorization of this paper. Ideas of the nature and significance of emergent strategy are often associate with the work of Mintzberg $(1972,1978)$ and other writers who have been associated with Mintzberg (Mintzberg and McHugh, 1985; Mintzberg and Waters, 1982, 1985; Mintzberg, Brunet, and Waters, 1986; Mintzberg, Otis, Shansie, and Waters, 1988; and Mintzberg and Austin, 1996). Mintzberg argues that deliberate strategy is associated with managerial control and is aimed at 'ensur[ing] that managerial intentions are realized in action' while emergent strategy emphasizes 'coming to understand through the taking of actions what those intentions should be in the first place (Mintzberg et al, 1998, p189, emphasis added).

Mintzberg has also argued that much of the conventional strategy literature is 'riveted on the realization of explicit intentions' (Ibid, 1998, p189) and therefore on implementation, largely to the exclusion of the emergent. Emergent strategy is much more interested in seeking to explain the manner in which those "explicit intentions" are adapted to provide new understandings in a dynamic environment. Such a conceptualization of the strategy formulation process allows an emphasis on strategic learning and enables us to give space to the organization's ability to experiment. In spite of this rather sympathetic notion of the way in which organizations might take an active position in experimenting, learning and playing with strategy formulation most of the evidence Mintzberg and others refer to, is of a rather unplanned process of emergence. Mintzberg and Waters (1985, p270) identify 7 "forms of strategy", which invariably present emergent strategy as the unintended outcome of more deliberate managerial policy. 
Weick (1979) argues that management is inextricably bound in a process of sense making which relies on the ex-post rationalization of past experiences. The conventional view which underlies strategic management consistently extols the virtue of a planning, followed by action cycle in which 'thinking must end before action begins-that formulation must be followed by implementation, (Mintzberg et al, 1998, p195). This conceptualization of strategic "enactment" and emergence is closely in keeping with a social constructionist view of the organizational milieu. A constructionist view would be loath to separate strategy formulation from implementation since seeing such social action as construction would suggest that any attempt to dis-aggregate such social action would be seen as arbitrary.

A social constructionist view of strategic action would certainly regard the understanding of organisational strategies as being enacted only through their practical implementation and involvement with the social world. From the constructionist perspective strategies can never be separated from their social and historical environment. Strategies only become what they are accepted as through social interaction, enactment and reinterpretation. A strategy can only become meaningful through the process of it's acceptance within the organization and acceptance cannot be enabled without modification. The very process of communication and "learning” cannot be done other than through a process of discourse which is irredeemably subjective and socially interpreted.

Some writers have sought to foreground the role of organisation culture in the strategy development process (Johnson, 2000). Others have attempted to gauge the cognitive mapping of managers' approaches to strategic variables using structured interview techniques (Daniels, et al, 1995; Daniels, et al, 1994). Hellgren and Melin (1993) concentrate their attention on the strategic thinking of CEOs, in contrast this paper will present an interpretive analysis of the interactions within a management team.

Whittington (1996) argues for a strongly process oriented approach to practice, practitioners and research of strategising as distinct from strategy (see also Alvesson, 2001). Whittington (1996) locates such an approach with early contributions to the literature such as Pettigrew (1985) and Johnson (1987) who are characterised as "exploring how organisations come first to recognise the need for strategic change and then actually to achieve it” (Whittington, 1996, 
p732). The researching of strategic practice approach attempts to show "how managers do strategy".

There are inspirational parts to doing strategy - the getting of ideas, the spotting of opportunities, the grasping of situations. But there is also the perspiration - the routines of budgeting and planning..., the sitting in expenditure and strategy committees... (Whittington, 1996, p732).

This paper takes such explanation and understanding seriously and tries to examine the practice of strategising performance measurement at the micro level by reporting a field study of the interactions of a management team which adopted a committee process to design and implement a system of performance measurement. This style of research follows from Whittington's call for "researchers to do more than manipulate large statistical databases" in order to understand the "nitty-gritty" [of] "local routines and practice" (ibid, p732). While the main emphasis of process research may remain on explaining the trajectory of the whole organisation the development of a stream of research, which seeks to understand the work of managers in formulating strategy by examining their day to day routines will provide "insight into how managers interact in decision-making and achieving cognitive change” (ibid, p734, see also Huff, 1990; Mintzberg, 1973).

In this paper the process which is examined relates to practical aspects of the determination of performance measures and critical success factors. The literature on performance measurement is very long established. More recently in the normative and practitioner literatures, concern has focussed on issues such as the relative significance of non-financial measures and the value of multiple measures. In the accounting literature Simons $(1990,1991)$ has argued that the links between management control systems and strategic management have been poorly understood. While in the popular literature the advent of the balanced scorecard (Kaplan and Norton, 1992, 1996) has provided clear efforts to position performance measurement and control systems as strategic tools. Kaplan and Norton (1996) argue that the balanced scorecard facilitates the formulation of strategy and provides a vital technique for the translation and communication of strategy throughout the organisation. Simons (1991) argues that management control systems, which include performance measurement systems, provide managers the opportunity to adopt adaptive management techniques. Simons suggests that managers adopt interactive practices in order to adapt their actions to changes in the environment facing the organisation. 
Simons (1995) identifies four aspects of what he describes as the strategic control process. He describes these as constituting the four levers of the strategic dynamic. The four levers or elements comprise: belief systems; boundary systems (see also Llewellyn, 1994, 1998); diagnostic control systems and interactive control systems.

Simons categorises performance measurement systems, such as the balanced scorecard as being part of an organisation's diagnostic controls. But in light of his observation that an appropriate control of strategy must combine aspects of each system it could be argued that any formulation of a system of performance measurement must take account of all four aspects. The experience of our research within the case organisation would suggest that the formulation was strongly influenced by belief and boundary systems. As we will discuss in the ensuing section the prior beliefs, functional knowledge and functional position within the organisation all appear to influence attitudes and group interaction at times during the formulation meetings.

The "groundwork" of strategy development is identified by Eden (1993) as consisting "of the following group activities: articulating strategic vision; identifying strategic issues; ... option generation and scenario building and the identification of stakeholders and their possible response in relation to their own goals (p117, emphasis in original). Eden (1993) goes on to identify five activities which follow from the formulation process including the development of a strategic control system involving a review of strategic performance and the performance of strategy. This paper is an attempt to examine, an aspect of this latter activity, at the micro level within a single organisation. The paper aims to make a contribution to our understanding of strategy formulation, in particular that related to the identification and adoption of performance measures. The paper uses an ethnographic approach to contribute to an area of literature which is of increasing significance but relatively underdeveloped in terms of the application of, in depth, field research techniques.

\section{Implementing a Performance Measurement System: Organising the Organisation}

This section of the paper attempts to relate the formulation story through a selective but hopefully illustrative and "representative" selection of exchanges, which are presented here as significant themes of the processes we observed. We have come to view the formulation 
process in this manner after an extended period of interaction with the organisation. Our hope is very much that the themes we prevent will provide the reader with valuable insights into the organisation and its managers. Only in this we can we hope to provide a rich understanding of the effects of such system changes within organisations. We see our approach in this section of the paper as part of the response to the concern of other writes to provide rich understandings of accounting and related control technologies within organisations (Boland and Pondy, 1983; Ahrens and Dent, 1998; Alvesson and Deetz, 2000).

Analysis of the interview transcripts combined with research notes written at the time of the meetings led to the identification of the following three themes: a somewhat surprising lack of knowledge among staff about the business and its environment; a degree of conflict and disagreement which seemed to presage the ability of the management team's ability to reach compromise and agreement and finally the emergence of understandings and meanings in a gradual, often unpredictable manner. In certain circumstances it appeared that the functional post help by participants came to play a significant part in the views they expressed and the positions they took on particular issues. We interpret such instances as evidence of people's interest in negotiating and maintaining intra-organisational boundaries (Llewellyn, 1994). These themes will be further evidenced in the following sections.

Organisational Boundaries: Attempting to Create a 'Common' Knowledge - Throughout the sessions the participants discussed a variety of aspects of the organisation. These discourses were marked initially by a good deal of uncertainty among the participants. The following exchange, begun by the Operations Manager, was typical of these early discussions.

Where are we making our money? Are we making it through catching, are we making it through trading? Which area? I don't know. What is the greenweight (see list of terms appendix 2) return on [the] ...different areas? [and] ...by species. Should we be targeting one vessel only for a skin-off product? Should we have three or four H and G vessels? (see list of terms - appendix 2). Should we have a skin on and an H and G vessel - where are the returns for us? Well we don't know that at this stage of the game (Operations Manager).

This brought the following response:

We are analysing the results mainly by vessel but not by greenweight per species. We haven't got the systems in place at the moment to deliver the information that we need (Company Accountant).

From this conversation it seems the Operations Manager was uncertain as to profitability of particular activities and species, what information was available and also what direction the 
company should be going in. Having an incomplete grasp of the information the Company Accountant was producing would tend to indicate a lack of understanding across functional boundaries within the organisation. Or at least such an exchange might be seen as indicative of the process of boundary maintenance (Cooper, 1990, 1992, Llewellyn, 1994, 1998). Alternatively the Operations Manager may have been making a different point about a lack of confidence in the quality and reliability of the accounting information. On balance the more likely interpretation would seem to support a lack of knowledge as to the profitability of species and organisational activities. This was confirmed in the comments of the Company Accountant.

The Operations Manager believed the lack of information was affecting his decision making. Decisions had to be made on vessels in July or August (it was now June) for the following fishing season (which runs from 1 October to 30 September). The consequence of agreeing to unsuitable conditions would be that losses could be sustained for an entire year, before the company would have the opportunity to re-negotiate the contract. The meeting provided an opportunity to express some of the uncertainty and frustration of the managers.

I really don't know what direction we should be targeting ourselves at this stage of the game and its very late in the day to not have a lot of confidence in what way we should be going (Operations Manager).

Contracts for vessels lasted for the entire fishing year, so once they were signed the company was committed to those variables (for example what would be caught, how the much would be paid in catching fees etc). But the Operations Manager was aware that contracting decisions would have to be taken

... I'll probably start talking contracts with Mike [owner of vessel A] when I am down South this time. A lot of discussion from Trevor's [General Manager] and my point of view will be [based] on gut feelings rather than hard analysis (Operations Manager).

Since the company had available to it more vessels than it had quota the Operations Manager wanted to determine what vessels were able to make the best contribution given a set quantity of quota. Later in the same session, questions were raised about the squid season and the returns made. Again there were uncertainties disclosed when the information was discussed:

I compared the squid sales for two of our vessels, A and B, and because vessel A had a big squid sale at a good price to customer $\mathrm{X}$ it distorted their return. Vessel B has more sales but because the product happened to go to a different customer its returns look a lot lower (Company Accountant). 
Was that because Jenny (Marketing Manager) got an abnormally high price from the customer for that product, or because the product from that vessel was better? (Operations Manager).

Well I don’t know that (Company Accountant).

The Marketing Manager interjected:

The grading of the product on that vessel was spot on. That's why we managed to secure a good price for that product (Marketing Manager).

The grading of product is critical. The crew on board the vessels graded the squid by size and weight. A large proportion of the squid would be purchased by a single customer, who's processing equipment would be set up to process particular sized squid. If they purchased under 200 gram squid and got sent larger squid they would be unhappy as this would cause production inefficiencies. Equipment would need to be reset and this would be time consuming and inconvenient. The Marketing Manager explained that if the case organisation was able to ensure that the product grading was accurate (for example, under 200 gram product was in-fact under 200 gram) her customer would be willing to pay a higher price.

It seemed that in this example there was uncertainty as to why the prices received were higher, yet the information was readily available through the Marketing Manager. Therefore the uncertainty arose not because the information was unavailable but because the information was not communicated and discussed. This lack of communication was consistent with the exchange recounted earlier that the Operations Manager was not clear as to what information the Company Accountant was producing. In both these cases and others encountered through out the discussions some uncertainties were not related to the information itself but rather the lack of communication.

There is evidence that the management team met infrequently to discuss results and issues. The indications were of a low degree of communication across functional areas within the company. In addition there was little evidence of systematic informal communication (Dent, 1987, 1991; Preston, 1986). For example over the period July and August, the management team meet four times and in every case the meetings were arranged for the purpose of the key performance indicators project. No other meeting for the management team as a whole was held during this time to discuss other issues. During the later key performance indicator meetings, the full management team did not attend. In the month of September, there was no meeting of the full management team. Individual members of the management team are frequently away from the corporate offices located in central north Island NZ, sometimes on 
the South Island of NZ attending to vessel and product issues. Such logistical issues made it harder for the full management team to meet together. In contrast to Preston (1986) there seemed little evidence of extensive informal interaction among managers.

Discussions would often be limited and would frequently involve only two managers. Information analysed, for example, on how much money was being made by a vessel, would generally be discussed between the Company Accountant and the General Manager. Also information would often be gathered on an 'ad-hoc' basis and the Company Accountant commented that often insufficient time would be made available for gaining an in-depth understanding of the information.

Through formal discussions it became evident that some uncertainties arose because of the costing system. When asked how much profit was made from squid sales the Company Accountant said:

We sold X tonnes of squid to one customer. The squid was caught by two vessels and the gross profit between vessels varied from 12 to 18 percent. This occurred even although the sales price were exactly the same because vessel A got allocated the quota that cost us \$X per tonne and vessel B got allocated the quota product that cost us \$Y per tonne (Company Accountant).

In cases such as this the margins made on the sales were reflecting the costs that had been allocated to the vessel rather than the profits being achieved. Quota accounted for a large proportion of the company's production costs and therefore the method on which it was allocated would have a significant effect when analysing profitability. A decision was made to review the method of costing quota.

It seemed that there was a genuine lack of information on certain aspects of profitability, which contributed to uncertainty in decision-making. However in other cases even when information was available it was not always utilised because of poor communication. There are clear implications here for the formulation of a system of performance measurement but other issues also arise. Such concerns over availability of information and communication might be seen as closely related to issues of intra-organisational boundaries (Cooper, 1992; Llewellyn, 1994). It is questionable whether such “communication” issues, which may well reflect attempts to maintain functional boundaries by withholding information or retaining access within ones own area could be solved through formal system approaches (Alvesson, 
2001). Issues of organisational culture are relevant here which would require further in depth study to comment upon in any serious way. But it seems somewhat doubtful that any formal system built on KPI's and critical success factors could address questions related to the informal work of boundary maintenance. Individual attempts to "hide" information or delay its disclosure would be very difficult to overcome through a formal system of performance measurement which failed to address issues of culture.

Disagreements, Perspective and Negotiation - During the sessions there were often disagreements. This section explores some of the difficulties in reaching agreement that occurred and how they were dealt with.

One area where many disagreements occurred was the choosing of key performance indicators for the customer perspective. The team had chosen 'quality product' as a critical success factor, which was to 'provide product within specification'.

One issue which influences the quality of product is that the company's minimum order is one container. A container holds approximately seventeen thousand kilograms of product. Therefore if the price per kilogram was four dollars for example, then a container of fish would be over sixty thousand dollars. If the customer requests a significant discount on the product because of its poor quality then the revenue at stake is considerable.

The Marketing Manager appeared not to want measures of rejects, while all the other participants wanted to have a measure that captured rejects. As shown above the discussion was lengthy and there appeared to be no way the Marketing Manager would agree to some measure of rejects. The Finance Manager sought to resolve the disagreement by saying:

Why don't we try a measure for percentage of customers who reject our product and if we find that there are no rejects or claims or that the information we gather serves no purpose then we can stop using this KPI. Is there agreement on this? (Finance Manager).

Yes (General Manager, Operations Manager, and Company Accountant).

Even although the Marketing Manager did not approve this key performance indicator she did not comment any further on this issue. The two key performance indicators chosen were:

1/ The percentage of product that meets our specification; 
2/ The percentage of customers who reject, or make a claim against, the product.

Throughout the many meetings held for the purpose of selecting the critical success factors and key performance indicators, the issue of customer service and satisfaction had come up a number of times. The sessions also provided the opportunity for staff to discuss problems they were having. An example of the type of problem discussed at the sessions follows:

I've got a situation where our customer ordered a quantity of product from us - we are currently arranging the shipping details and have confirmed that product with the customer. He has now turned around and said I don't want any more of this garbage, the grading is so bad. In terms of his satisfaction - he hasn’t got any (Marketing Manager).

There seemed to be considerable support, among the management team for measures which could capture customer satisfaction or track customer retention. The issue came up again when discussing the nature that the market development critical success factor might take:

What do we measure ... is it to get more customers? (Company Accountant).

To make sales... You want to develop markets, you want to develop new customers, you want to develop existing customers. It's easier to develop an existing customer than develop a new customer (Marketing Manager).

You have to keep your existing ones happy - that’s your first priority (Operations Manager).

Do we want to look at customer retention? (Finance Manager).

Customer retention was recorded as a potential measure to capture information on the customer perspective. When asked if the team wanted to add 'customer retention' as a measure there was again disagreement.

Shouldn't that (retain customers) apply from quality. Didn't we decide that we didn't need a customer - as long as we had a quality product? ... If we provide quality products then there should be no reason why we don't keep the customer. (Company Accountant)

Do you want us to take out retain customers? (Finance Manager)

I think that would be a critical mistake. (Marketing Manager)

In spite of this recognition of significance of retaining customers, the following discussion shows that subsequently no agreement was reached on measures of customer retention or satisfaction.

I think we could focus on the product and get the quality right and yet annoy our customers and therefore lose them. If we are not going to have any measure of our service or anything beyond the physical product then we are not picking up on customer satisfaction, which I see as being the focus here. Customer satisfaction may be mainly influenced by the quality of the product, but we can't assume that is all. (Finance Manager) 
Our customer is critical... (Company Accountant)

What could we have for customer service? (General Manager)

We could have a customer satisfaction rating. If you are going to have a satisfaction rating you could say that ninety five percent of our customers are very happy with our service, in all regards, product quality, service etc. That would mean actually asking them via a survey or some other method (Finance Manager).

We could survey our customers? (General Manager)

We could use customer satisfaction instead of customer retention. Then we don't have to measure retaining them - we are asking them to rate us so we can make sure we focus on the areas that they judge as important or areas they say we need to improve on (Finance Manager).

I feel I would rather use that time and energy to actually look after those customers rather than asking them what they think of us or how good or how bad we are. I would rather say to them what' s happening right now, what's going on? (Marketing Manager).

It was even suggested by the General Manager that if it was an issue of time and energy taken up by surveys that "we have our own customer satisfaction survey that we do ourselves based on the ad-hoc information we collect”. This was not agreed to either. In the end the General Manager gave the Marketing Manager the choice on the issue by asking "do we want some measure of customer satisfaction included or not?”

The Marketing Manager responded negatively by suggesting that while “customer satisfaction and retention is important ... it is [not] a critical success factor”. She continued to justify such a conclusion by arguing that the company did not "process product .... [to a] significant enough [extent]”. Consequently the Marketing Manager would not support any measures from a customer perspective except those based on the quality of the product and in this case no compromise was reached. A customer based measure was never included.

Discussion of customer measures has been used to show that it was difficult to reach agreement in the formulation of the key performance indicators system. Disagreements occurred at the level of choosing critical success factors, key performance indicators and the targets used for the key performance indicators. However the customer perspective was not an isolated case where the participants found it difficult to reach agreement. The participants also had difficulty agreeing on other critical success factors, for example in the human resources area. With regard to balancing outcome measures with process measures, the case organisation 
again encountered difficulty. The case organisation had difficulty in identifying process measures that were acceptable to team members.

Agreement or Compromise: Emergent Strategic Understandings - The strategic management literature is typically seen as predominantly normative and prescriptive. In one important area of the literature this is much less the case. There is considerable debate and significant evidence that strategy is emergent rather than planned (Mintzberg, 1978, 1987; Mintzberg et al, 1998; Hopwood, 1983; Dent, 1991; Simmons, 1990, 1991). The process of formulation of the key performance indicators system at the case site was marked by disagreement and active debate as illustrated above. While the disagreements were not always resolved without significant compromise, and perhaps forcing in some instances, a feature of the process was the emergence of meaning and the development of understanding over time. Individual members of the group developed understandings and appeared to create shared meanings through interaction in the meetings (Boland, 1993, Scapens and Macintosh, 1996; Giddens, 1984). The nature of these interactions can be illustrated by the discussion over certain key terms. Often the terms seem mundane but exchanges tended to indicate that terms often held different meanings for different individuals (Alvesson, 2001). One area where understandings emerged over time was the area of market development. The management team had wanted to have a critical success factor based on its market strategy but were unsure how this might best be quantified.

What is a definition for marketing? (Company Accountant).

We haven't got one yet - we can't seem to agree on what we are trying to achieve in our marketing focus for the company. What is critical? We know what we are trying to achieve generally but we haven't isolated what is critical to the company and its marketing strategy (Finance Manager).

To identify and develop profitable relationships: to identify suitable markets (General Manager).

Bearing in mind our marketing strategy I see it as a development thing. I see it as organic because it constantly grows and it moves - development in its wider sense. Development of what we have got in terms of product - taking it, marketing and customers. We don't start with one thing all the time, we might start off with a market, for example Mexico. We were aware of a market then developed the customer. Sometimes you have a product and go forward from that angle. So as I see it you have got all of those things combined together. The strategy is then formed. It may develop along the way - it may develop first. You then use that to maximise your performance and or return (Marketing Manager).

Can I abbreviate what you've just said? It's called market development. What aspects of market develop do we want to develop over this year. Market Development would be the critical success factor for us (General Manager). 
Through further discussion the team was able to agree on a compromise that defined the 'market development' critical success factor as 'to grow both customer and market presence'.

What aspects of market development are we concerned with? What is the measure of the market having been developed? (General Manager).

We determine the profitable markets for the core product that we have. We didn't make too much on the hoki fillet product last year. We obviously want to make more this year (General Manager).

It's the return, the most profitable deal you can get, which should be focused on (Operations Manager).

We already know that the US and Europe market pay more for hoki fillet product than Australia does. We want to establish a presence in those markets so that we can drive the profitability up (General Manager).

Are we saying that to grow both customer and market presence we need to make sales to new markets? What's critical is to develop a new market for hoki which will be the US and Europe (Finance Manager).

While it seemed there was uncertainty as to the marketing focus, the term 'market development' emerged from the discussion as did an understanding of what the company wanted to do to achieve this. A term 'direct export percentage' emerged from the same discussion:

What is the measure of the market having been developed? (General Manager).

There is no point in us sitting here selling our product through product brokers (Marketing Manager).

We need to look at sales made by us directly rather than brokered sales (General Manager).

So how would we define that? (Finance Manager).

Percentage of sales made through direct sales (General Manager).

Direct export percentage (Marketing Manager).

Product brokers are New Zealand firms who purchase bulk quantities of fish products. Initially when the company first began producing its own seafood products, these were sold through product brokers. However the company had wanted to export its own products directly to customers. The company had established that direct exporting would provide it with a number of advantages. One of these was the additional profit margin that was available. Calculations had shown that while there would be additional costs of exporting its own 
products, these costs were less than the additional margins that could be derived by exporting products directly itself. The company chose a target for the key performance indicator to be ‘70 \% of all sales made are exported by the company'. This would help drive the company’s profitability.

This lengthy discussion started with an uncertainty as to how the marketing focus should be captured and ended with a shared understanding of the marketing focus. The selection of the measure of direct exports was then agreed on. This shows that while the process was long and drawn out, the team did come to a shared understanding and agreement on the measure. Subsequent discussions with the General Manager revealed that his focus had been on increasing the percentage of products exported by the company. However discussions with other staff showed that they previously did not share this understanding.

It was not just terms, meanings and understandings that emerged from the discussions. Through the discussions a new critical success factor emerged. During the session, to choose measures for the human resource critical success factor, the issue of information availability arose again. The team had previously agreed to its critical success factors. Yet through further discussions a new critical success factor emerged.

We certainly have got the people with the right skills but I don't think we have got the information systems in place to deliver the information we require, when we require it (Operations Manager).

The company has grown quickly and the information systems are just not keeping pace...Well it seems everyone agrees that we need better information systems, yet unless this is given the attention it requires nothing will change. It's a fine idea to improve information systems but if its not focused on and no one spends the time then it doesn't happen (Finance Manager).

Let's include systems development as a critical success factor. If we think systems development is critical for the company's success then we need to focus on that and make sure we develop measures to ensure that we are achieving it (General Manager).

There was agreement that the new critical success factor would be established. In order to ensure that the development of information systems got the support required to make it happen, a significant amount of funding was agreed on to allow the development to occur. 


\section{Discussion: The Evidence on Emergence}

The experience of the case organisation is notable in a number of respects. Much of the normative literature on performance measures does note the difficulty of formulation but at the same time this literature tends to suggest that such problems can be fixed by involving managers, by careful planning and so on. Particular issues seemed to be characteristic of the process experienced at the case site. The difficulties of reaching agreement on performance measures seemed to be a feature of much of the discussions among team members. It was also noted above that agreement on strategic issues seemed to be characterised best as a process.

The previous section discussed some of the issues relating to the process of developing and implementing a key performance indicator system at the case organisation. Theme one related to the different perspectives and disagreements that were encountered by the case organisation in the development of its system of key performance indicators. The second theme was of the uncertainty and lack of knowledge, exhibited by the participants throughout the process. The third theme of the process was emergent understandings. It was noted that although there was uncertainty exhibited and there were often disagreements, individuals members of the group developed understandings and appeared to create shared meanings through interaction in the meetings.

Agreement on strategic issues and critical success factors took the form of an emergent iterative process (Mintzberg, 1972, 1978; Mintzberg and Waters, 1982, 1984; Mintzberg and Austin, 1996; Mintzberg et al; 1998). These aspects were described in the previous section. Another issue which seemed to feature strongly throughout the identification and development of the critical success factors and performance indicators was a tendency for the team to return rather unerringly to financial measures. This again presents a conflict to the populist literature on performance measurement (Lynch and Cross, 1993; Kaplan and Norton 1992, 1996; AusIndustry, 1996). This literature argues for the avoidance of purely financial and outcome based measures. This literature demands balance by incorporating non-financial measures in addition to financial measures and process measures as well as outcomes measures.

Mintzberg et al (1998) recognize a certain incoherence in what they describe as emergent strategic behaviour. The problem which they encounter results from a tendency to introduce some deliberation into their model. As Mintzberg et al (1998) try to incorporate "learning" 
into their conceptualizations of emergent strategy they run up against the need to recognise reflective actors. They state that 'we have associated emergent strategy with teaming. But this is not quite right, if emergent strategy means, literally, unintended order, then patterns may just form, driven by external forces or internal needs rather than the conscious thoughts of any actors' (Ibid, 1998, p195; the concept of teaming used here appears to be related to Senge 1990; see also Cyert and March, 1963; Argyris, 1976; Schon, 1983). But they continue that 'real teaming takes place at the interface of thought and action, as actors reflect on what they have done' (Mintzberg et al, 1998, p195). This seems a rather restricted view of learning and “teaming”, rather as if teaming can somehow only be done consciously. This is a significant misunderstanding of what constitutes both team based behaviour and learning, both of which might reasonably be expected to have both reflective, conscious and un-reflexive, unconscious elements (Weick, 1979).

The evidence from the case organization supports a broadly emergent view of strategy formulation in the context of performance measurement in particular. The emergent processes which are reported in the previous section may be seen as adding to what is conventionally seen as a Mintzbergian post-rationalization of experimental behaviour. But as to whether all of the discourse and interaction which occurred during the meetings and out of meeting discussions in the case organization were indicative of the conscious actions of reflective actors seems an unsupportable claim.

The evidence presented in the case section of the paper details aspects of the day to day practice and gives some impression of the tone of the exchanges among practicing managers. The exchange on the identification of critical success factors between the management group described on pages 13 through 16, involving principally the finance and marketing managers is illustrative of the micro-level conflicts which can shape overall strategic behaviour. The briefer discussion presented on page 18 on the emergence and broad acceptance of the term “direct export percentage” provides some insight on a view of emergent strategy as being something more than the Mintzbergian post-rationalization of experimental behaviour. In this instance we see the emergence of a performance measure through group dialogue which influenced future behaviour in the organization.

Mintzberg et al (1998) briefly discuss the contribution of chaos theory to strategic management. A central concept of chaos theory is the idea that simple and apparently 
insignificant deterministic relationships can potentially produce enormously influential but unpredictable outcomes (Levy, 1994, p168).

The traditional approach to management has led to an emphasis on control, order, and predictability. Chaos and disorder have been seen as inimical to the very notion of organization, destructive forces to be constrained. Even the teaming process, which may seem initially disorderly, is ultimately expected to be institutionalized in the routine of the organization. Some management writers argue that disorder and chaos are normal properties of organizations (Nonaka, 1988; Stacey, 1992). Stacey suggests that managers should engage with these disturbances as a way to enable innovation. These writers see organizations dynamic systems in a permanent state of disequilibrium and argue that from such a perspective 'managers should deliberately inject disturbances into the operations so that the resulting inconsistencies can generate new knowledge’ (Mintzberg et al, 1998, p222/3).

Ideas from chaos theory challenge such fundamental 'taken-for-granted' management assumptions. Constructs which relate to conventional ideas about planning are particularly challenged: that "long-term futures are knowable"; that "the environment is a given"; that successful businesses "adapt”. Chaos theory suggests, in contrast, that irregularity is a fundamental property of the organization and that small, disturbances can have large effects. Such ideas challenge the concepts that suggest organizational uncertainty can be reduced by relying on structures, control systems, rules and procedures. Instead managers must be ready to adapt.

Many of the disagreements which were referred to in an earlier section of the paper were resolved through discussion and compromise. In other instances fundamental disagreements were left unresolved. Alternative explanations are possible but at times it seemed that members of the management 'team' were anxious not to reveal too much. Probably, not unreasonably, some managers went into the process with concerns as to what information would be generated from any new measures implemented. Alvesson (2001) argues that it would be naïve to expect managers to behave or feel any differently (see also Preston, 1986). 


\section{Conclusion}

The case organisation encountered difficulties in developing its key performance indicators system. A major difficulty was the disagreements that occurred. Why was it so difficult to reach agreement? While it is difficult to be certain on why obtaining agreement was troublesome, the paper has outlined some general observations as to the process. The paper has sought to describe three themes earlier which characterised the processes at the company. We might connect aspects of two of these themes to the problem of getting agreement on the identification and nature of the relevant performance measures. They are theme one uncertainty and lack of knowledge and theme three emergent understandings.

Some of the problems can be argued to be simply the expected outcomes of group dynamics among managers who have differing backgrounds and special interests and knowledge. We might characterise these as relating in part to the participants' different business models, different functional focuses, and anxieties over revealing information they might regard as personal and critical to their place in the organisation. The paper has sought to illuminate the last of these issues in the previous section since such staff concerns are rather poorly treated in much of the organisational literature.

It remains to be said that the difficulty of getting tidy and effective resolutions, which clearly identify performance measures within a system of critical success factors ought not to be expected to be just a matter of getting people together. There are fundamental issues affecting individual managers and their self perceptions which are likely to make it important to feel that they are able to keep some important, what they might regard as “personal” and perhaps partly tacit information, to themselves (Gherardi, 2000; Gherardi and Nicolini, 2000).

Overall we feel that conceptualising the development of strategy as an emergent process seems valuable and insightful. Our case material and interpretation seems to support the use of a social constructionist view of the processes which are involved in the formulation of the organisational performance measures. In documenting the development of the organisational performance measurement system in the case organisation we describe the way in which the measures emerge from, at times, quite intense discourse during relatively constrained social interactions. 
Appendix 1 - Summary of meetings held in the case organisation

\begin{tabular}{|c|c|c|}
\hline Date & Purpose of the meeting & Present \\
\hline 26 June 1998 & $\begin{array}{l}\text { Introduce the concept of key } \\
\text { performance indicators }\end{array}$ & $\begin{array}{l}\text { General Manager } \\
\text { Operations Manager } \\
\text { Marketing Manager } \\
\text { Finance Manager } \\
\text { Company Accountant }\end{array}$ \\
\hline 16 July 1998 & Identify critical success factors & $\begin{array}{l}\text { General Manager } \\
\text { Operations Manager } \\
\text { Marketing Manager } \\
\text { Finance Manager } \\
\text { Company Accountant }\end{array}$ \\
\hline 27 July 1998 & $\begin{array}{l}\begin{array}{l}\text { Selection of key performance } \\
\text { indicators for: }\end{array} \\
\text { Quality product } \\
\text { Market development }\end{array}$ & $\begin{array}{l}\text { General Manager } \\
\text { Operations Manager } \\
\text { Marketing Manager } \\
\text { Finance Manager } \\
\text { Company Accountant }\end{array}$ \\
\hline 3 August 1998 & $\begin{array}{l}\text { Selection of key performance } \\
\text { indicators for: } \\
\text { Access to quota } \\
\text { Catching capacity } \\
\text { Human resources }\end{array}$ & $\begin{array}{l}\text { General Manager } \\
\text { Operations Manager } \\
\text { Finance Manager } \\
\text { Company Accountant }\end{array}$ \\
\hline 10 August 1998 & $\begin{array}{l}\text { Selection of key performance } \\
\text { indicators for: } \\
\text { Return on equity }\end{array}$ & $\begin{array}{l}\text { General Manager } \\
\text { Operations Manager } \\
\text { Finance Manager } \\
\text { Company Accountant }\end{array}$ \\
\hline
\end{tabular}




\section{Appendix 2: List of Terms}

\section{Greenweight:}

A term used to refer to fish in its whole state before any processing has occurred. This can be contrasted with processed weight, which is the weight of the product remaining after processing has occurred. GWT is used to refer to greenweight tonnes.

\section{H \& G Vessels:}

Vessels which process fish to a state where it is headed and gutted but processed no further.

\section{Outsourcing:}

A term used within the case study organisation, which refers to the activity of buying other company's fish products and on-selling these at a higher price, thus making a margin on the sale.

\section{Recovery rate:}

The rate at which fish products are obtained through processing.

For example a recovery rate of $33 \%$ would be achieved if 3 tonnes of whole fish were processed into 1 tonne of fish fillets. 


\section{References}

Ahrens, T. and Dent, J. E. (1998) Accounting and Organizations: Realizing the Richness of Field Research, Journal of Management Accounting Research, 10, p.1-39.

Alvesson, M. (2001) Organisational Culture, Sage.

Alvesson, M. and Deetz, S., (2000) Doing Critical Management Research, Sage.

Argyris, C. (1976) Increasing Leadership Effectiveness, New York: Wiley.

AusIndustry (1996) Key performance indicators manual: A practical guide for the best practice development, implementation and use of KPIs. Melbourne: Pitman Publishing.

Boland, R. J., (1993) Accounting and the Interpretive Act, Accounting Organizations and Society, Vol 18 No 2/3 pp. 125-146.

Boland, R.J. Jr. and Pondy. L R, (1983) Accounting in Organizations: a Union of Natural and Rational Perspectives, Accounting Organizations and Society, pp. 223-234.

Cooper, R. (1990), “Organization/Disorganization”, in Hassard, J. and Pym, D. (Eds), The Theory and Philosophy of Organizations, Routledge, London.

Cooper, R. (1992), "Formal Organization and Representation: Remote Control, Displacement and Abbreviation", in Reed, M. and Hughes, M. (Eds), Rethinking Organizations New Directions in Organizational Theory and Analysis, Sage, London.

Covaleski, M.A., \& Dirsmith, M.W. (1990). Dialectic tension, double reflexivity and the everyday accounting researcher: On using qualitative methods. Accounting, Organizations and Society, 15(6): 543-573.

Cyert, R. M., and March, J. G, (1963) A Behavioral Theory of the Firm, Englewood Cliffs, NJ: Prentice Hall.

Daniels, K., de Chernatony, L. and Johnson, G. (1995) Validating a method for mapping managers' mental models of competitive industry structures. Human Relations, 48[9].

Daniels, K., Johnson, G and. de Chernatony, L. (1994) Differences in managerial cognitions of competition. British Journal of Management, 5, 521-530.

Dent, J. F., (1991) Accounting and Organizational Cultures: A Field Study of the Emergence of a New Organizational Reality, Accounting Organizations and Society, Vol 16 No 8, pp. 705-732.

Dent, J., (1987) Tensions in the Design of Formal Control Systems: A Field Study in a Computer Company, p.119-145, in Accounting and Management: Field Study Perspectives, W. Bruns and R.S. Kaplan (eds), Harvard Business School Press.

Eden, C. (1993) Strategy development and implementation: cognitive mapping for group support, in Hendry, J., G. Johnson and J Newton (eds) strategic thinking, leadership and the management of change, Wiley.

Gherardi, S. (2000) Practice-based Theorizing on Learning and Knowing in Organizations, Organization, Vol. 7, No. 2, p211-224.

Gherardi, S. and Nicolini, D. (2000) To Transfer is to Transform: The Circulation of Safety Knowledge, Organization, Vol. 7, No. 2, p329-349.

Giddens, A., (1984) The Constitution of Society, Cambridge: Polity Press.

Hellgren, B. and Melin, L. (1993) The role of strategists' ways-of-thinking in strategic change processes, in Hendry, J., G. Johnson and J Newton (eds) strategic thinking, leadership and the management of change, Wiley. 
Hopwood, A.G., (1983) On trying to study accounting in the contexts in which it operates, Accounting, Organizations and Society, pp. 287-305.

Huff, A. S. (1990) Mapping strategic thought. Chichester: Wiley.

Johnson, G (2000) Strategy through a cultural lens: Learning from manager's experience. Management Learning, Thousand Oaks.

Johnson, G. (1987) Strategic Change and the Management Process. Oxford: Basil Blackwell.

Johnson, G., S. Smith and Codling B. (2000) Microprocesses of institutional change in the context of privatisation. The Academy of Management Review; Mississippi State.

Kaplan R.S. and Norton P., (1996) Using the Balanced Scorecard as a Strategic Management System, Harvard Business Review, p. 75-85.

Kaplan, R.S., \& Norton, D.P. (1992). The Balanced Scorecard - Measures That Drive Performance. Harvard Business Review, 70(1): 71-79.

Langfield-Smith, K. (1997) Management Control Systems and Strategy: A Critical review, Accounting, Organizations and Society, Vol. 22, No. 2, pp. 207-232.

Levy, D. (1994) Chaos Theory and Strategy: Theory, Application, and Managerial Implications." Strategic Management Journal, 15, p167-178.

Lindblom, C. E. (1959) The Science of Muddling Through. Public Administration Review, 19, 2, p79-88.

Llewellyn, S. (1993). Working in hermeneutic circles in management accounting research: some implications and applications. Management Accounting Research, 4: 231-249.

Llewellyn, S. (1998) Boundary work: costing and caring in the UK social services, Accounting, Organizations and Society, Vol. 23 No. 1, pp. 23-48.

Llewellyn, S., (1994) Managing the Boundary; How Accounting is Implicated in Maintaining the Organization, Accounting Auditing and Accountability Journal, Vol 7 No 4, pp. 4-23.

Lynch, R.L., \& Cross, K.F. (1993). Performance measurement - the balanced scorecard. In Handbook of Cost Management. Boston, Mass. Warren Gorham Lamont.

Mintzberg, H. (1972) Research on Strategy-Making," Proceedings of the 32nd Annual Meeting of the Academy of Management, Minneapolis.

Mintzberg, H. (1973) The nature of managerial work. New York, Harper and Row.

Mintzberg, H. (1978). Patterns in Strategy Formulation, Management Science, 24(3): 934-48.

Mintzberg, H. (1979) The Structuring of Organizations. London: Prentice Hall.

Mintzberg, H. (1987) Crafting Strategy, Harvard Business Review, 65(4):66-75.

Mintzberg, H., and Austin, B. (1996) Mirroring Canadian Industrial Policy: Strategy Formation at Dominion Textile from 1873 to 1990. Canadian Journal of Administrative Sciences, 13, 1, p46-64.

Mintzberg, H., and McHugh, A. (1985) Strategy Formation in an Adhocracy. Administrative Science Quarterly, 30, p160-197.

Mintzberg, H., and Waters, J. A. (1982) Tracking Strategy in an Entrepreneurial Firm. Academy of Management Journal, 25, 3, p465-499.

Mintzberg, H., Brunet, J. P, and Waters, J. A. (1986) Does Planning Impede Strategic Thinking? Tracking the Strategies of Air Canada from 1937 to 1976. Advances in Strategic Management, 4, p3-41. 
Mintzberg, H., Otis S., Shamsie, J., and Waters, J. A. (1988) "Strategy of Design: A Study of 'Architects in Co-Partnership."' In J. Grant, ed., Strategic Management Frontiers, Greenwich, CT. JAI Press, p311-359.

Morgan, G. (1988). Accounting as Reality Construction: Towards a New Epistemology for Accounting Practice. Accounting, Organizations and Society, 13(5): 477-485.

Nonaka, I. (1988) Toward Middle-Up, Down Management. Sloan Management Review, 29, 3, Spring, p9-18.

Nonaka, I., and Takeuchi, H. (1995) The Knowledge-Creating Company: How Japanese Companies Create the Dynamics of Innovation New York: Oxford University Press,

Pettigrew, A. M. (1985) The Awakening Giant: Continuity and Change in Imperial Chemical Industries, Oxford: Blackwell.

Preston, A., (1986) Interactions and Arrangements in the Process of Informing, Accounting, Organizations and Society, Vol 11, No 6, pp $521-540$.

Scapens, R. W. and Macintosh, N., (1996) Structure and Agency in Management Accounting Research: A Response to Boland's Interpretive Act, Accounting Organizations and Society, Vol 21 No 7/8, pp 691-697.

Schon, D. A. (1983) "Organizational Learning." In G. Morgan, ed., Beyond Method: Strategies for Social Research Beverly Hills, CA: Sage.

Senge, P M. (1990) The Fifth Discipline: The Art and Practice of the Learning Organization New York: Doubleday.

Simons R., (1990) The Role of Management Control Systems in Creating Competitive Advantage: Creating New perspectives, Accounting, Organizations and Society, Vol 15 No 1/2, pp 127-143.

Simons R., (1991). Strategic Orientation and Top Management Attention to Control Systems, Strategic Management Journal, Vol 12, pp 49-62.

Simons R., (1995) Levers of Control: How managers use innovative control systems to drive strategic renewal, Harvard.

Stacey, R. (1992) Managing Chaos: Dynamic Business Strategies in an Unpredictable World London: Kogan Page.

Weick, K. E. (1979) The Social Psychology of Organizing, Reading, MA: Addison-Wesley.

Weick, K. E. (1995) Sensemaking in Organizations, Thousand Oaks, CA: Sage Publications.

Whittington, R. (1996) Strategy as Practice. Long Range Planning, 29[5], p.731-735.

Zairi, M., \& Steve, L. (1994). Performance measurement: A Challenge for total quality and the accounting professions. Asia Pacific Journal of Quality Management, 3(2): 26-41. 


\section{OTHER PAPERS IN THIS SERIES}

1. Lawrence, S.L. Rational and social aspects of management accounting practice: report of a field study, June 1990.

2. Northcott, D.N. Capital budgeting in practice: past research and future directions, August 1990.

3. Cheung, J., Vos., E. and Low, C.K. IPO underpricing in New Zealand, September 1990.

4. Van Peursem, K.A. Extant research in public sector accountability, March 1991.

5. Van Peursem, K.A. New Zealand auditor perceptions: difficult and critical audit procedures, July 1991.

6. Alam, M. The budgetary process from information processing perspectives, September 1991.

7. McCracken, T. \& Hooper, K. The New Zealand goods and services tax (GST): identifying the problem areas, September 1991.

8. Lowe, A. Strategic management accounting, September 1991.

9. McCracken, T. Pricing: a review of contemporary approaches, February 1992.

10. Cheung, J. Estimating costs of capital for small ventures, March 1992.

11. Cheung, J., Vos, E., \& Bishop, D. Pre-holiday returns in the New Zealand share market, May 1992.

12. Van Peursem, K.A. Accountability for social policy: a moral framework, June 1992.

13. Alam, M. \& Poulin, B.J. Budget as a discipline: lessons from a turnaround enterprise, December 1992.

14. Raj, M. Pricing options on short and long-term yields using stochastic arbitrage based models, May 1993.

15. Godfrey, A. \& Hooper, K. Domesday Book: its significance as an accounting document, June 1993.

16. Van Peursem, K.A., Lawrence, S.R. \& Pratt, M.J. Health management performance: a classification and review of measures and indicators, July 1993.

17. Coy, D. \& Goh, G.H. Overhead cost allocations by tertiary education institutions 1989-91, September 1993. 
18. Coy, D., Dixon, K. \& Tower, G. The 1992 annual reports of tertiary education institutions: quality, timeliness and distribution, November 1993.

19. Van Peursem, K.A. \& Tuson, C. Financial reporting in Area Health Boards 1987-1992, January 1994.

20. Vos, E. \& Davey, H. Time consistent accounting standards as a necessary condition for relating "point in time" accounting information to market returns, April 1994.

21. Coy, D., Buchanan, J. \& Dixon, K. The users of New Zealand tertiary education institutions' annual reports: who are they and what information do they seek? December 1994.

22. Coombes, R. \& Davey, H. The New Zealand accountant's role in environmental accountability, December 1994.

23. Wells, P.K. Marketing regulation and compliance programmes, November 1995.

24. Haslam, J. Analysis of accounting as at the end of the Napoleonic war: towards a critical theoretical history of the prescribing of accounting by the British State, November 1995.

25. Haslam, J. The British state and the prescribing of accounting, 1815-1830: a focus upon the regulating of friendly societies and savings banks in the post-Napoleonic war context, November 1995.

26. Haslam, J. Accounting publicity and the revolution in government, November 1995.

27. Haslam, J. Accounting history as critique of the present: a critical theorising of interfaces between accounting nd the British state of the early 1840s, November 1995.

28. Dosa, L., Gallhofer, S. \& Haslam, J. Accounting's location in a transition process: a focus upon Hungary, November 1995.

29. Gallhofer, S. \& Haslam, J. Accounting on the road: turnpike administration in early nineteenth century Britain, November 1995.

30. Ciancanelli, P., Gallhofer, S., Haslam, J. \& Watson, R. Pay systems and social ideology: the case of profit related pay, November 1995.

31. Jenkin, Erica and Van Peursem, Karen A. Expert systems in auditing: New Zealand auditor perspectives, November 1995. 
32. Wells, P.K. Marketing regulation and compliance programmes: attitudes and reactions of New Zealand marketing managers in 1988, November 1995.

33. Davey, H.B., Bowker, T. \& Porter, B. New Zealand's controlled foreign company regime, November 1995.

34. Davey, H.B., Barnes, H. and Porter, B. External environmental reporting: the need for a New Zealand standard, November 1995.

35. Lawrence, Stewart, Rethinking professional ethics: a religious metaphor for accountants, November 1995.

36. Ciancanelli, P., Watson, R., Gallhofer, S. \& Haslam, J. Alternative perspectives on finance: a critical analysis, November 1995.

37. Gallhofer, Sonja \& Haslam, J., Beyond accounting: the possibilities of accounting and "critical" accounting research, November 1995.

38. Gallhofer, Sonja, "It really challenged everybody": accounting and critical and feminist pedagogy, January 1996.

39. Gallhofer, Sonja, and Haslam, Jim, The direction of green accounting policy: critical reflections, January 1996.

40. Wells, P.K., Marketing regulation and compliance programmes: attitudes and reactions of New Zealand marketing managers in 1995, February 1996.

41. Pratt, Michael and Coy, David, Managing teaching allocations in a university department: the TAMM model, June 1996.

42. Coy, David and Pratt, Michael, The spider's web: politics and accountability in universities, June 1996.

43. Doolin, Bill, Organisational roles of decision support systems, June 1996.

44. Beale, Bob and Davey, Howard, The nature and origins of comprehensive income, August 1996.

45. Davey, Howard, and Holden, Mark, Emerging directions in the evaluation of foreign subsidiary performance, September 1996.

46. Kelly, Martin, A personal perspective on action-research, October 1996.

47. Doolin, Bill, Defining decision support systems, November 1996. 
48. Gallhofer, Sonja, Haslam, Jim and Pratt, Mike, Developing environmental accounting: insights from indigenous cultures, November 1996.

49. Ciancanelli, Penny, Gallhofer, Sonja, Haslam, Jim and Watson, Robert, In the name of an enabling accounting: critical reflections developed and enhanded through an analysis of accounting and profitrelated pay, November 1996.

50. Lowe, Alan, The role of accounting in the processes of health reform: providing a "black box" in the cost of blood products, November 1996.

51. Coy, David and Buchanan, John, Information technology diffusion among business professionals: Preliminary findings of a longitudinal study of spreadsheet use by accountants 1986-96, February 1997.

52 Beale, Bob and Davey, Howard, Total recognised revenues and expenses: an empirical study in New Zealand, March 1997.

53. Coy, David, Nelson, Mort, Buchanan, John and Jim Fisher, Spreadsheet use by accountants in Australia, Canada and New Zealand: preliminary findings, March 1998.

54. Wells, P.K., Manapouri: catalyst or consequence? October 1998.

55. Lowe, Alan, Tracing networks through case studies, October 1998.

56. Kim, S.N. and Mfodwo, K., Prospects for the establishment of Islamic banking in New Zealand: a contextual analysis, November 1998.

57. Van Peursem, K.A., Method for a methodology: a new approach for the middle range, November 1998.

58. Locke, Joanne and Perera, Hector, An analysis of international accounting as a catalyst for the reintegration of accounting research, August 1999.

59. Julian, Aileen and Van Peursem, Karen, Ethics education and the accounting curriculum: can ethics be taught?, August 1999.

60. Van Peursem, K.A., Wells, P.K. and L Huillier, B. Contracting services in SMEs: A New Zealand professional accounting firm case study, September 1999.

61. Lowe, Alan, Accounting in health care: providing evidence of a real impact, September 1999. 
62. Alam, Manzurul and Wells, Philippa, Control systems of government-owned business enterprises: a critical analysis of the New Zealand model, November 1999.

63. Kelly, Martin, In Praise of Holistic Education in Accounting, December 1999.

64. Smith, Susan Ann and Coy, David, The quality of city council annual reports, 1996-97 and 1997-98: Preliminary findings, March 2000.

65. Hooper, Keith and Low, Mary, Representations in accounting: the metaphor effect, June 2000.

66. Dixon, Keith, The impact of management control across a hospital system, August 2000.

67. Lowe, Alan, Accounting information systems as knowledge-objects: some effects of objectualization, August 2000.

68. Locke, Joanne and Lowe, Alan, A market test of the ranking of accounting journals: an Australasian perspective, October 2000.

69. Francis, Graham, Humphreys, Ian and Jackie Fry, Lessons for other counties from the privatisation, commercialisation and regulation of UK municipal airports, December 2000.

70. Hooks, Jill, Coy, David and Howard Davey, Information disclosure in the annual reports of New Zealand electricity retail and distribution companies: preliminary findings, January 2001.

71. Lowe, Alan, Methodology, Method and Meaning in Field Research: Intensive Versus Extensive Research Styles in Management Accounting, March 2001

72. Van Peursem, Karen, Locke, Joanne and Harnisch, Neil, Audit Standard Analysis: An Illocutionary Perspective on the New Zealand Going Concern Standard April 2001

73. France, Necia, Francis, Graham, Lawrence, Stewart and Sacks, Sydney, Measuring Performance Improvement in a Pathology Laboratory: A Case Study, April 2001

74. Hooper, Keith and Davey, Howard, Preferences on Learning Options in Accounting Education: A New Zealand/Asian Perspective, May 2002

75. Lowe, Alan and Locke, Joanne, A Paradigm Sensitive Perspective on the Ranking of Accounting Journals: A Web-based survey Approach, May 2002

76. France, Necia, Francis, Graham and Lawrence, Stewart Redesigning Clinical Laboratory Services: Securing efficient diagnoses for New Zealanders, January 2003 